\title{
Yellowing Disease in Zucchini Squash Produced by Mixed Infections of Cucurbit yellow stunting disorder virus and Cucumber vein yellowing virus
}

\author{
Francisco M. Gil-Salas, Jeff Peters, Neil Boonham, Isabel M. Cuadrado, and Dirk Janssen
}

First, fourth, and fifth authors: Instituto Andaluz de Investigación y Formación Agraria, Pesquera, Alimentaria y de la Producción Ecológica (IFAPA), La Mojonera, Almería, Spain; and second and third authors: Food and Environment Research Agency, Sand Hutton, York, United Kingdom.

Accepted for publication 13 June 2011.

\begin{abstract}
Gil-Salas, F. M., Peters, J., Boonham, N., Cuadrado, I. M., and Janssen, D. 2011. Yellowing disease in zucchini squash produced by mixed infections of Cucurbit yellow stunting disorder virus and Cucumber vein yellowing virus. Phytopathology 101:1365-1372.

Zucchini squash is host to Cucurbit yellow stunting disorder virus (CYSDV), a member of the genus Crinivirus, and Cucumber vein yellowing virus (CVYV), a member of the genus Ipomovirus, both transmitted by the whitefly Bemisia tabaci. Field observations suggest the appearance of new symptoms observed on leaves of zucchini squash crops when both viruses were present. When infected during controlled experiments with CYSDV only, zucchini plants showed no obvious

inconspicuous symptoms restricted to vein clearing on some of the apical leaves and the virus accumulated progressively between 15 and 60 dpi. Similar accumulations of virus followed single inoculations with the potyvirus Zucchini yellow mosaic virus (ZYMV) and plants showed severe stunting, leaf deformation, and mosaic yellowing. However, in mixed infections with CYSDV and CVYV, intermediate leaves showed chlorotic mottling which evolved later to rolling, brittleness, and complete yellowing of the leaf lamina, with exception of the veins. No consistent alteration of CVYV accumulation was detected but the amounts of CYSDV increased $\approx 100$-fold and remained detectable at 60 dpi. Such synergistic effects on the titer of the crinivirus and symptom expression were not observed when co-infected with ZYMV.
\end{abstract} symptoms and the virus titer decreased between 15 and 45 days postinoculation (dpi), after which it was no longer detected. CVYV caused

The whitefly (WF) Bemisia tabaci (Gennadius) (Aleyrodidae: Hemiptera) has been of increasing importance throughout the world as a pest of food, fiber, and ornamental plants since the early 1980s. It is also a vector of more than 100 plant viruses recognized as species in the genera Crinivirus (Closteroviridae), Begomovirus (Geminiviridae), Carlavirus (Flexiviridae), or Ipomovirus (Potyviridae) (33). Cucumber vein yellowing virus (CVYV) and Cucurbit yellow stunting disorder virus (CYSDV) are the two main viruses transmitted by this WF species in crops of the family Cucurbitaceae. CVYV has a positive-sense singlestranded RNA genome of $9.7 \mathrm{~kb}$ and is member of the genus Ipomovirus, family Potyviridae $(31,36)$. This virus has a limited host range, including a number of cucurbitaceous plant species $(13,32)$, and its geographic distribution is confined to the oriental Mediterranean Basin. CVYV was first described in Israel (13) and subsequently recognized as the most prevalent disease affecting cucumber in plastic-covered greenhouses in Jordan (4). CVYV has also been reported from Turkey (78), Sudan (17), Tunisia (77) Iran (7), Spain (16), Portugal (42), and France (37). Symptoms induced by CVYV in cucumber are severe vein yellowing on the youngest leaves and stunted growth of plants with reduced fruit production (13). The virus is transmitted mechanically and by $B$.

Corresponding author: D. Janssen;

E-mail address: dirk.janssen@juntadeandalucia.es

* The $\boldsymbol{e}$-Xtra logo stands for "electronic extra" and indicates that the online version contains one supplemental table and Figure 1 appears in color.

doi:10.1094/PHYTO-12-10-0343

(C) 2011 The American Phytopathological Society
Additional keyword: synergism. tabaci in a semipersistent manner (45). In contrast, symptoms produced by CYSDV (genus Crinivirus, family Closteroviridae) are interveinal chlorosis and necrosis, and stiffness or brittleness of the lower leaves, resembling early senescence and nutritional deficiencies in cucurbits $(11,63)$. In cucumber, chlorotic flecks are first produced in intermediate and older leaves; these enlarge and coalesce to produce large areas of chlorosis, necrosis forms in these chlorotic areas, and leaves die prematurely. CYSDV has a bipartite genome consisting of two positive-sense single-stranded RNA segments of $9.1 \mathrm{~kb}$ (RNA1) and $7.9 \mathrm{~kb}$ (RNA2) encapsulated in separate flexuous virions $(3,11)$. It is also transmitted semipersistently by $B$. tabaci and causes phloem-limited infections (11). First reported in the United Arab Emirates in 1982 (29), it has spread throughout the Middle East (59), the Mediterranean region $(18,19,43,57,63)$, North America $(34,75)$, and Eastern Asia (40).

The gradual colonization of the WF B. tabaci in crops across different countries and continents and the subsequent expansion of CYSDV and CVYV across the Mediterranean during recent decades has led to mixed infections in cucurbit crops $(30,77)$. In greenhouses from southern Spain, CYSDV has been present in cucurbitaceous crops since 1992 (11,63), and CVYV was introduced in the fall of 2000 (16). Both viruses are independently transmitted by the same vector $(25,60)$ and produce distinctive symptoms on leaves that are easily recognized in cucumber in the case of mixed infections, reaching proportions $\leq 100 \%$ of greenhouse-grown crops (60). In Spain, the introduction of CVYV in crop-producing areas where B. tabaci and CYSDV were endemic caused significant economic losses to farmers because of reduced plant development and the appearance of deformations and symptoms on cucumber fruit (30). 
Disease control in areas with a high density of intensive crop production requires knowledge of all factors that affect defined plant pathosystems. In the case of Spain, reservoir plant hosts for WFs (54) and for CYSDV and CVYV (32) are present in the region and subject to control strategies against yellowing disease in cucumber. However, in regions such as Almeria (southeastern Spain), cucumber and zucchini squash (Cucurbita pepo L. var. Zucchini) are produced simultaneously in $\approx 4,000$ ha each of greenhouses. Gil-Salas et al. (25) found that B. tabaci, sampled from zucchini squash crops during the year 2006, contained high amounts of CYSDV and CVYV. Before the year 2001, CYSDV was the sole WF-transmitted virus present in cucurbitaceous crops. Control of the vector was not a primary objective for farmers producing zucchini squash, because they perceived no damage to production and no specific symptoms were observed. Since 2001 and the establishment of CVYV in the region, relative yields have reduced to 90 to $85 \%$ (kg/ha) (12) and discrete CVYV-like symptoms and evident leaf yellowing have been observed in zucchini squash. The yellowing symptoms are observed during both spring and autumn crop seasons but the highest incidences are recorded during the former, occasionally up to $33 \%$ of plants (14). However, it is not clear whether the expression of these symptoms can be explained by the infection with CVYV or whether it results from a synergism following mixed infections with CYSDV. In the present article, we compare symptom expression and levels of CVYV and CYSDV viruses in zucchini squash in single and mixed infections. In addition, results were contrasted with those obtained for plants infected with the potyvirus Zucchini yellow mosaic virus (ZYMV) in single and mixed infections with either CVYV or CYSDV.

\section{MATERIALS AND METHODS}

Incidence of leaf yellowing and association with CVYV and CYSDV under natural conditions. During the months of February and March 2011, six commercial greenhouses from the province of Almeria (Spain) were visited; the incidence of leaf yellowing symptoms was visually evaluated in each greenhouse by examining $\approx 500$ zucchini squash plants following a W-shaped itinerary (39) and expressed as the percentage of total plants. In addition, young leaves from randomly chosen symptomatic and asymptomatic plants were collected for detection of CYSDV and CVYV as described below. The $\chi^{2}$ test statistic was used to evaluate whether there was an association between the expression of leaf yellowing and viral infections in a contingency table.

Viruses, plants, and WFs. Cucumber (Cucumis sativus 'Albatros') (Rijk Zwaan, Iberica, Spain) was grown in a temperaturecontrolled greenhouse at $25^{\circ} \mathrm{C}$ with a photoperiod of $14 \mathrm{~h}$ of light and $10 \mathrm{~h}$ of darkness, and used as source plants to maintain the following viral cultures: CVYV (31), CYSDV (isolated at IFAPA from cucumber crops in Almeria, Spain, in 2000), and ZYMV (isolated in 2003 from zucchini squash crops in Almeria, Spain, and obtained from the Plant Health Inspection Service in La Mojonera, Spain). CVYV and ZYMV were maintained by sap inoculation (31) and CYSDV by WF transmission (76). Both infected and uninfected plants were grown in insect-proof screen cages located within greenhouses where temperature was partially controlled (22 to $28^{\circ} \mathrm{C}$ ). Approximately four weeks later, plants that showed typical symptoms of virus infection were used as the virus source.

Zucchini squash (Cucurbita pepo 'Paquita') (Ramiro Arnedo, Spain) plants, susceptible to CVYV, CYSDV, and ZYMV, were grown in the temperature-controlled greenhouse $\left(25^{\circ} \mathrm{C}\right)$ until development of the first true leaf. At this stage, plants were introduced into insect-proof cages and infected with CYSDV using viruliferous $B$. tabaci WFs or sap inoculated with CVYV or ZYMV on the following day. After inoculations, the plants were introduced and grown in an insect-proof greenhouse.
B. tabaci WFs used for CYSDV maintenance and transmission were identified as Q biotype (based on the sequence of the mitochondrial cytochrome oxidase subunit 1 gene and identical to GenBank sequence number DQ302946) (data not shown) and reared on eggplant (Solanum melongena L.) in separated insectproof screen cages at $25 \pm 2^{\circ} \mathrm{C}, 14 \mathrm{~h}$ of light and $10 \mathrm{~h}$ of darkness. WF adults of the same age were obtained by collecting the insects that emerged during a given $24-\mathrm{h}$ period.

Experimental design. Groups of 10 zucchini squash plantlets were infected with a combination of two viruses (CYSDV+ CVYV, CYSDV+ZYMV, or CVYV+ZYMV). For inoculations of test plants with CYSDV, $\approx 300$ newly emerged ( 0 to $24 \mathrm{~h}$ ) adults were introduced onto CYSDV-infected cucumber source plants, allowing an acquisition feeding period of $48 \mathrm{~h}$. The viruliferous adults were then collected and inoculated in groups of 10 to healthy zucchini squash seedlings for a period of $24 \mathrm{~h}$ of inoculation feeding, after which the plants were sprayed with imidacloprid to kill the insects. Inoculations of test plants with CVYV and ZYMV were carried out mechanically by rubbing cotyledons after dusting with Carborundum. Inocula were extracted by grinding cucumber leaves in phosphate buffer ( $\mathrm{pH}$ 8.5). Double inoculation was performed by preparing extracts from equal fresh weights of young leaves of source plants and mixing the extracts. Mock inoculations and individual inoculations with CYSDV, CVYV, and ZYMV were employed as controls. Mock inoculations of CYSDV were done with virus-free WFs and of CVYV and ZYMV with inoculation buffer. At 15, 30, 45, and 60 days postinoculation (dpi) (as counted after the inoculation of the second virus in the case of mixed inoculations), $0.2 \mathrm{~g}$ of tissue from the second apical leaf was removed for analysis by real-time reverse-transcription polymerase chain reaction (RT-PCR). The study was done during the months of September to November 2006 and repeated during the months of March to May 2007, September to November 2007, and March to May 2008.

Virus detection. Total nucleic acids were extracted from leaf samples according to Accotto et al. (2). The primers and probes used for CVYV and CYSDV amplification were as described by Gil-Salas et al. (25). Those for amplification of the internal controls were based on a fragment within the $18 \mathrm{~S}$ ribosomal region of the Cucurbita mitochondrial genome (24). The primers (ZYMVFor, 5'-CCGCCCTCGGAAAAGCT-3' and ZYMV-Rev, 5'-TGT CTTGGTGGAGGGCTTGT-3') and probe for ZYMV were designed using Primer Express software (version 2.0; Applied Biosystems, Cheshire, UK) within the nuclear inclusion protein $b$ coding region of the virus genome (accession number AB127936). The probe ZYMV-Fgl (5'-CTGAGACAGCAC TTCG-3') was labeled with 6-carboxyfluorescein (FAM) as 5' terminal reporter dye and with minor groove binder-nonfluorescence quencher (MGB-NFQ) as 3' quencher dye. RT-PCR using the real-time PCR primers (viruses and internal control) produced amplified fragments of the expected size that were subsequently cloned, sequenced, and used to obtain standard curves as described (25). The sequence identity of the virus and internal control standard was confirmed after comparison with GenBank sequences AB127936 (ZYMV) and AF206895 (C. pepo 18S ribosomal RNA gene). All the probes and primers were supplied by Sigma Genosys (Haverhill, UK), except for the CYSDV-Lid and ZYMV-Fgl probe, that were supplied by Applied Biosystems (Table 1). Real-time RT-PCR assays and relative quantitative analyses were performed as described (25). For graphical presentation of results and statistical comparison by regression analysis of virus quantification from collected samples, the mean normalized expression (MNE) was calculated according to Gil-Salas et al. (25). During the analyses, the interaction effects from single and mixed infections, dpi, the season, and its repetition effects were investigated using general linear model statistics. In total, 960 samples from 10 zucchini squash plants at four consecutive time points postinoculation for each virus combination and con- 
trol infection during two different seasons and during two consecutive years were analyzed. All effects were tested at the 5\% significance level. Analyses were performed using GenStat 10.2 statistical software.

\section{RESULTS}

Incidence of leaf yellowing and association with CVYV and CYSDV under natural conditions. Percentages of zucchini squash expressing leaf yellowing symptoms from 500 plants in six commercial greenhouses each were $0,0.5,5.0,5.1,8.3$, and $15.2 \%$. The presence of CYSDV and CVYV was analyzed in leaf samples from 41 plants with and 53 plants without symptoms. A cross-tabulation of the disease category (leaf yellowing and no leaf yellowing), the detection of single and mixed infections of CYSDV and CVYV, and absence of these viruses are presented in Table 2. All of the plants expressing leaf yellowing had mixed infections $(100.0 \%)$. In contrast, asymptomatic plants contained predominantly CYSDV or CVYV (34 and 17\%, respectively) or none of the two viruses $(45.3 \%)$. The null hypothesis of independence of symptom expression and the presence of virus was rejected $\left(\chi^{2}=86.25, \mathrm{df}=3, P<0.0001\right)$.

Symptom expression. Inoculation of zucchini squash with CVYV produced inconspicuous symptoms in most plants, restricted to vein clearing on some of the apical leaves at 15 to $30 \mathrm{dpi}$ (Fig. 1A and B). No symptoms have been observed on plants with single infections of CYSDV (Fig. 1C). However, in mixed infections with CYSDV and CVYV, most plants showed chlorotic mottling on intermediate leaves, which evolved later to complete yellowing of the leaf lamina-with exception of the veins-and rolling and brittleness of the leaves (Fig. 1D and E). Single and mixed inoculations (with either CVYV or CYSDV) of ZYMV produced vein clearing symptoms on apical leaves at $15 \mathrm{dpi}$ (Fig. $1 \mathrm{~F}$ and $\mathrm{G}$ ) and, during the subsequent development of plants, severe stunting and leaf symptoms were predominant, expressed as deformation and yellow mosaic on the leaves (Fig. 1H and I).

Real-time RT-PCR. Real-time RT-PCR amplification of all plants infected with CVYV revealed detectable amounts of virus at 15 to 60 dpi. However, CYSDV was detected only during the entire study period when co-infected with CVYV and in single infections at 15 to $30 \mathrm{dpi}$. For the purpose of subsequent statistical analysis, the nil detections at 45 and 60 dpi found for
CYSDV after single inoculations were attributed with the value of to $4.1 \log \mathrm{MNE}$, which represented the limit of quantifiable amounts of virus defined by the minimum amounts of specific virus cDNA versus the maximum amounts of control S18 cDNA according to their respective standard curves (not shown). The accumulated analysis of variance results from all quantitative data collected showed that all effects were statistically significant, except for the factor "Year", which represents the repeat of the experiments throughout the two consecutive years. The significant interaction between single and mixed infections with CVYV and CYSDV ("Treatment"), dpi, and season $(P<0.001)$ indicate that the amounts of virus detected over time changed significantly with the seasonal repeat. This model accounted for $\approx 95.8 \%$ of the total variation in the data. Comparisons over different seasons and years showed that the amounts of CVYV detected were significantly higher during spring than during autumn seasons. Still, the amounts of CVYV were similar in the cases of single infections and mixed infections with CYSDV. Also, single infections with CYSDV showed this seasonal effect, although the amounts of virus were significantly lower when compared with mixed infections with CVYV (Table 3). In order to exclude the possibility that these seasonal changes in virus expression were derived from differences in the expression of the internal control in spring and autumn, the amounts of mitochondrial S18 RNA were compared for all single CYSDV- and CVYV-infected plants at 15 to $60 \mathrm{dpi}$. The average amounts of S18 cDNA detected per weight of zucchini squash leaf tissue samples $(n=320)$ were $17.52 \mathrm{ng} / \mathrm{g}$ during autumn and $14.32 \mathrm{ng} / \mathrm{g}$ during the spring seasons, and were not significantly different (95\% confidence level, Fisher's least significant difference). To facilitate the analyses, viral expression data from the four repeat experiments have been combined, and the effect of the interactions between single and mixed infections with CVYV and CYSDV and dpi is shown in Figure 2. Following inoculation, the amounts of CVYV in plants during single infections fluctuated in time but showed a gradual increase at 15 to $60 \mathrm{dpi}$. Similar progression and amounts were found when this virus was co-infected with CYSDV. After single infections with the Crinivirus sp., however, CYSDV decreased at 15 to 30 dpi. At 45 dpi, only 7 of 40 plants infected with CYSDV yielded very low, albeit detectable, amounts of virus; at $60 \mathrm{dpi}$, none of 40 plants showed positive real-time RT-PCR results (represented with the value of $-4.1 \log$ MNE in Figure 2). In con-

TABLE 1. Sequence of the primers and probes for the TaqMan real-time reverse-transcription polymerase chain reaction assay

\begin{tabular}{|c|c|c|c|c|c|c|}
\hline Primer $^{y}$ & Orientation & Sequence & $\left(5^{\prime}-3^{\prime}\right)$ & Position in sequence & Reporter $^{\mathrm{z}}$ & Quencher $^{2}$ \\
\hline CVYV-For & Forward & AY578085 & CGA AGG TCT CGA ATA AGC GTT C & $9518-9539$ & .. & $\ldots$ \\
\hline CVYV-Rev & Reverse & AY578085 & GAA TAC CCC ACA CCG AAC TTC A & $9613-9634$ & & \\
\hline CVYV-Pak & Probe & AY578085 & TAT TTA CGG TTT TAG TAA GAG TTT GGG ATC CGC AG & 9552-9587 & FAM & BHQ1 \\
\hline CYSDV-Rev & Reverse & AY242078 & TCT GGA TAT AAC CTT CAG ACA CTC CTT & $930-956$ & .. & $\ldots$ \\
\hline CYSDV-Lid & Probe & AY242078 & CTC CGT GCG CTC GTT AGG TAC CGG & $882-905$ & VIC & MGB-NFQ \\
\hline ZYMV-For & Forward & AB127936 & CCG CCC TCG GAA AAG CT & 196-212 & $\ldots$ & $\ldots$ \\
\hline ZYMV-Rev & Reverse & AB127936 & TGT CTT GGT GGA GGG CTT GT & 290-309 & .. & \\
\hline CUC18S-Rev & Reverse & AF206895 & GTG GTG CCC TTC CGT CAA T & $1044-1073$ & .. & $\ldots$ \\
\hline CUC18S-Ana & Probe & AF206895 & TCC GCC AGC ACC TTA TGA GAA ATC AAA GTC & $1120-1138$ & JOE & BHQ1 \\
\hline
\end{tabular}

y Cucumber vein yellowing virus (CVYV), Cucurbit yellow stunting disorder virus (CYSDV), and Zucchini yellow mosaic virus (ZYMV).

${ }^{\mathrm{z}}$ FAM, 6-carboxyfluorescein; VIC, PE Biosystems; JOE, 2,7-dimethoxy-4,5-dichloro-6-carboxyfluorescein; BHQ1, black hole quencher-1; MGB-NFQ, minor groove binder-nonfluorescence quencher.

TABLE 2. Two-by-four contingency table for the expression of leaf yellowing symptoms (LY) in zucchini squash and absence and presence of single and mixed infections of Cucurbit yellow stunting disorder virus (CYSDV) and Cucumber vein yellowing virus (CVYV) in plants from commercial greenhouses

\begin{tabular}{lcccrr}
\hline Numbers & CYSDV only & CVYV only & CYSDV + CVYV & None & Total \\
\hline LY & 0 & 0 & 41 & 0 & 41 \\
No LY & 18 & 9 & 2 & 24 & 24 \\
Total & 18 & 9 & 43 & 93 \\
\hline
\end{tabular}


trast to what was observed in the former case, the co-infection of CVYV had a pronounced effect on CYSDV during mixed infections. Although CYSDV infection followed a downward progression similar to that observed during single infections, the relative amounts were $\approx 100$ times higher at $45 \mathrm{dpi}$ (log MNE mean value of -2.088 in mixed versus -4.05 in single infections). During these mixed infections, all zucchini plants had detectable amounts of CYSDV at $60 \mathrm{dpi}$. A significant effect on the mean infection level and the slope of the linear regression equation of CYSDV when co-infected with CVYV is shown in Table 4.

As in the case of CYSDV and CVYV, the accumulated analysis of variance results obtained from infections of single and mixed infections of CYSDV and ZYMV showed that all effects were statistically significant, except for the repeat factor Year. Also a significant seasonal effect was observed. This model accounted for $\approx 95.1 \%$ of the total variation in the data. Inoculation of zucchini squash with ZYMV produced detectable amounts of virus that evolved in a way similar to CVYV. The viral load increased 10-fold at 15 to $45 \mathrm{dpi}$, followed by a reduction at $60 \mathrm{dpi}$. In contrast to what was observed for the ipomovirus, ZYMV did not alter the amounts and progression of CYSDV during the course of the experiments in mixed infections. At 45 dpi, only 15 of 40 plants infected with CYSDV yielded detectable amounts of virus when co-infected with ZYMV (versus 7 of 40 in single infections) and, at $60 \mathrm{dpi}$, the virus was detected in none of 40 plants, similar to what was observed during single CYSDV infections. When compared with single infections, however, the amounts of ZYMV detected were lower when co-infected with the crinivirus (Fig. 3). Although the differences in mean levels of ZYMV in single and mixed infections with CYSDV were not significant, the crinivirus had a clear effect on the rate of decline in infection levels (Table 4).
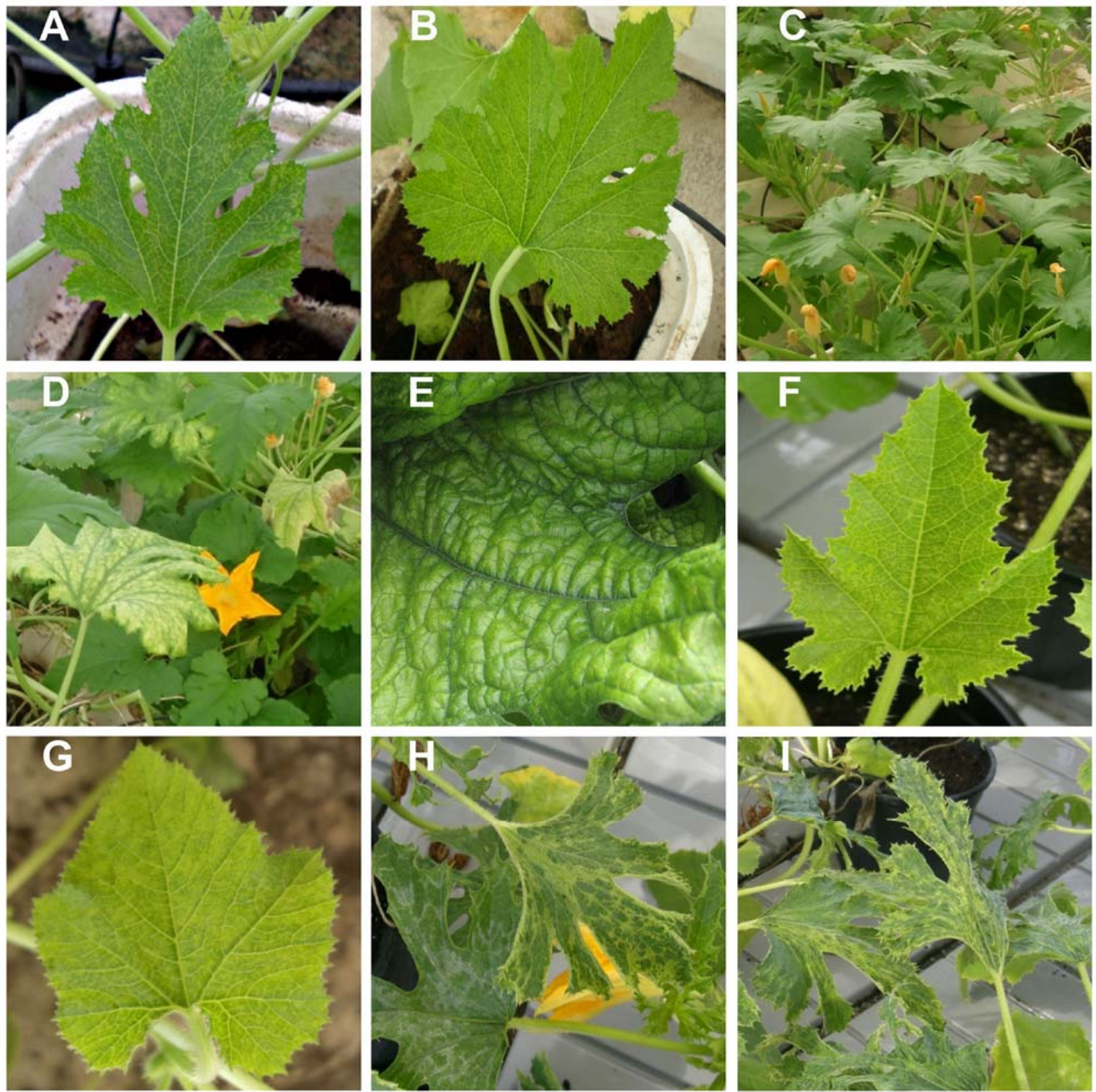

Fig. 1. Symptoms observed for single and mixed infections with Cucumber vein yellowing virus (CVYV), Cucurbit yellow stunting disorder virus (CYSDV), and Zucchini yellow mosaic virus (ZYMV), or co-infections of CVYV, CYSDV, and ZYMV in zucchini squash 'Paquita' plants. Zucchini squash plants A, singly infected with CVYV at 15 days postinoculation (dpi); B, co-infected with CVYV and CYSDV at 15 dpi; C, singly infected with CYSDV at 45 dpi; D, co-infected with CVYV and CYSDV at $45 \mathrm{dpi}$; E, co-infected with CVYV and CYSDV at 60 dpi (detail); F, singly infected with ZYMV at 15 dpi; G, co-infected with CVYV and ZYMV at $15 \mathrm{dpi}$; H, singly infected with ZYMV at 45 dpi; I, co-infected with CVYV and ZYMV at 45 dpi. 
Interactions between single and mixed infections with the ipomovirus CVYV and the potyvirus ZYMV and dpi are shown in Figure 4. When co-infected with ZYMV, the CVYV infection progressed similarly to the single inoculations; the amounts of virus detected were only approximately fivefold higher at 15 and $30 \mathrm{dpi}$ and lower at 45 and $60 \mathrm{dpi}$. Similarly, the co-infection of CVYV had marginally no significant effects on the progression of ZYMV infection (Table 4). The accumulated analysis of variance results for single and mixed infections of CVYV and ZYMV is shown in Supplemental Table 1.

\section{DISCUSSION}

Zucchini squash is a host for CYSDV but the infection is not associated with the expression of symptoms (9), and this observation was confirmed when we inoculated plants with viruliferous B. tabaci during our experiments. Plants infected with CVYV showed vein-clearing symptoms as described in squash, hence confirming their host status $(6,58)$. These symptoms are reminiscent of those produced in cucumber $(6,16)$ but less pronounced and often transient. However, at 45 to 60 dpi of co-infection with CVYV and CYSDV in zucchini squash, typical crinivirus infection symptoms were found, consisting of interveinal mottle on intermediate leaves, that evolved later to complete yellowing of the leaf lamina, except the veins, and rolling and brittleness of the leaves very similar to those observed on cucumber infected with CYSDV (1). Results from field surveys confirmed the existence of single and mixed infections with CVYV and CYSDV in zucchini squash under natural conditions but the expression of the leaf yellowing symptoms on this crop species was clearly associated with mixed infections of both viruses (Table 2). These observations suggest the existence of synergism between the ipomovirus and crinivirus. Zucchini squash infected with ZYMV under controlled conditions initially showed vein-clearing symptoms followed by leaf mosaic and leaf distortion and narrowing, similar to what was observed after co-infection with either CYSDV or CVYV (Fig. 1). If CYSDV and CVYV symptoms were present in mixed infections with ZYMV, they were undistinguishable from those produced by the potyvirus. Co-infections of different poty- viruses appear nonsynergistic and produce no symptom enhancement (20). Also, the combination between ipomoviruses and potyviruses, both genus members of the family Potyviridae, has been described to cause no changes in symptom severity, as is shown for Sweet potato mild mottle virus and Sweet potato feathery mottle virus (SPFMV) in sweetpotato (50).

The lack of effect on symptom expression in situations of mixed infections, either with different potyviruses or in the case of a potyvirus together with an ipomovirus, correlates with the accumulations of the respective viruses that remain similar to those found during single-virus infections (50). Likewise, levels of CVYV did not affect those from ZYMV and vice versa. (Fig.

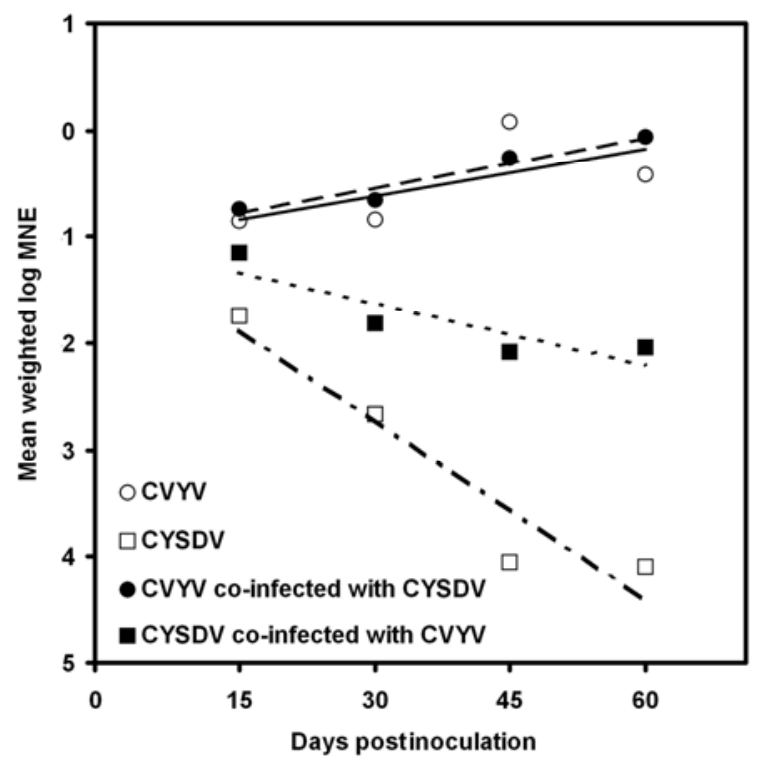

Fig. 2. Amounts (mean weighted log [mean normalized expression (MNE)]) against the number of days postinoculation in zucchini squash of Cucumber vein yellowing virus (CVYV) and Cucurbit yellow stunting disorder virus (CYSDV) during single and mixed infections. Average least significant difference between means was 0.61 .

TABLE 3. Virus levels (mean weighted log [mean normalized expression]) during single and mixed infections of Cucumber vein yellowing virus (CVYV) and Cucurbit yellow stunting disorder virus (CYSDV) in zucchini squash

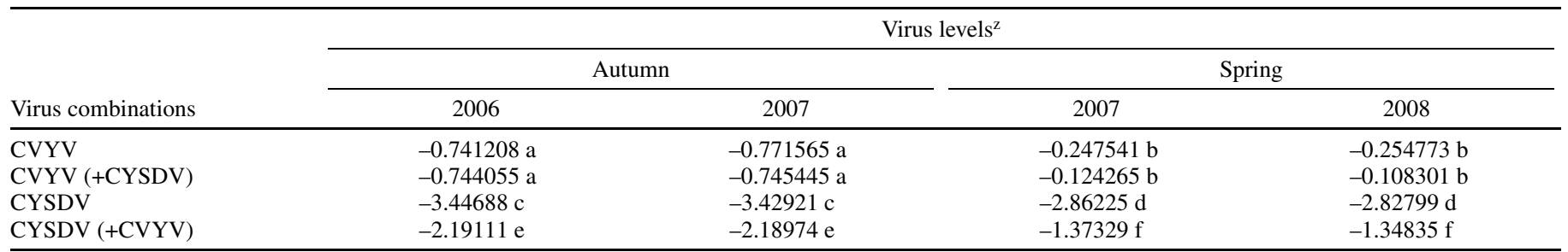

${ }^{\mathrm{z}}$ Each value is the mean of results from 10 plants at 15, 30, 45, and 60 days postinoculation. Values followed by the same letter are not significantly different (Fisher's least significant difference test, $P<0.05$ ).

TABLE 4. Linear equations and coefficients of determination $\left(R^{2}\right)$ of virus levels against days postinoculation from single and mixed infections of Cucumber vein yellowing virus (CVYV), Cucurbit yellow stunting disorder virus (CYSDV), and Zucchini yellow mosaic virus (ZYMV), and probability ( $P$ ) of effects of coinfection on the mean levels and slopes

\begin{tabular}{|c|c|c|c|c|c|}
\hline \multirow{2}{*}{\multicolumn{2}{|c|}{ Virus combinations }} & \multirow{3}{*}{$\begin{array}{c}\text { Equation of slope } \\
y=0.0146 x-1.0547\end{array}$} & \multirow{3}{*}{$\frac{R^{2}}{0.42}$} & \multicolumn{2}{|c|}{ Effect of treatment ( $P$ probability) } \\
\hline & & & & \multirow{2}{*}{$\begin{array}{c}\text { Mean infection level } \\
\ldots\end{array}$} & \multirow{2}{*}{$\begin{array}{c}\text { Slope } \\
\ldots\end{array}$} \\
\hline CVYV & nil & & & & \\
\hline CVYV & CYSDV & $y=0.0159 x-1.0283$ & 0.95 & 0.593 & 0.875 \\
\hline CYSDV & nil & $y=-0.0563 x-1.0315$ & 0.91 & . & $\ldots$ \\
\hline CYSDV & CVYV & $y=-0.0196 x-1.0401$ & 0.77 & $<0.001$ & 0.002 \\
\hline CYSDV & ZYMV & $y=-0.0425 x-1.5666$ & 0.86 & 0.240 & 0.915 \\
\hline
\end{tabular}


4). During the course of the present study, virus levels of ZYMV, CVYV, and CYSDV showed significant differences between tests carried out in March to May and September to November. Observations of seasonal variations in virus concentration have been attributed to temperature (47) and have also been observed in other pathosystems involving potyviruses (21), member species of the family Closteroviridae $(8,28,49)$, and CVYV $(24,60)$. However, independently from such seasonal changes, the presence of CYSDV in zucchini squash was detected during the first 4 weeks only, with decreasing levels at 15 to $30 \mathrm{dpi}$, and real-time RT-PCR yielded no quantifiable amounts beyond this period. When CVYV was co-inoculated together with CYSDV, the levels of the crinivirus in plants were significantly higher when compared with single infections, and remained present throughout the entire study period (Fig. 2). Because CYSDV symptom expression and virus accumulation are related in melon and cucumber $(22,46)$, this suggests that the synergistic effect of CVYV on CYSDV benefits the replication of CYSDV in zucchini squash with the appearance of symptoms that are novel to this plant species. Another example of synergistic effects on criniviruses described are Turnip mosaic virus and Lettuce infectious yellows virus (72).

Synergism represents one possible result from multiple pathogen infections, and occurs when co-infections lead to enhanced symptom expression or increased virus accumulation $(35,51$, 61,68). Synergistic interactions in plants resulting from mixed infections with two or more viruses are particularly relevant to control strategies of crop diseases. Sweet potato virus disease, a major constraint for sweet potato production, is caused by a synergistic interaction of the crinivirus Sweet potato chlorotic stunt virus (family Closteroviridae) and SPFMV (genus Potyvirus) $(35,41,56,62)$. Sugar beet displays yellowing symptoms when infected with Beet yellows virus (genus Closterovirus) and the rate of symptom expression is significantly enhanced when plants are co-infected with Beet mosaic virus (genus Potyvirus) (74). And the co-infection of Blackberry yellow vein associated virus (genus Crinivirus) and Blackberry virus $Y$ (family Potyviridae) has been associated with blackberry yellow vein disease, an emerging threat to blackberry production in the southern

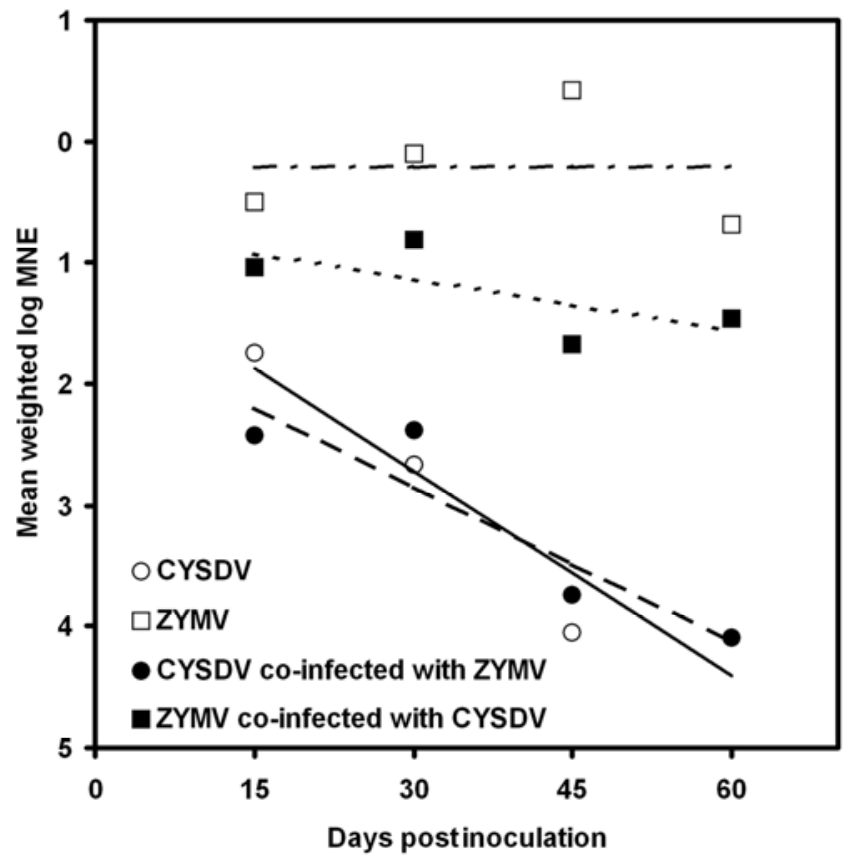

Fig. 3. Amounts (mean weighted log [mean normalized expression (MNE)]) against the number of days postinoculation in zucchini squash of Zucchini yellow mosaic virus (ZYMV) and Cucurbit yellow stunting disorder virus (CYSDV) during single and mixed infections. Average least significant difference between means was 0.7739 .
United States (64). Commercial tomato cultivars which carry the $S w-5$ resistance gene against Tomato spotted wilt virus (TSWV) (family Bunyaviridae) are widely cultivated commercially and limit TSWV damage. However, these plants are rendered susceptible to TSWV when preinfected with the crinivirus Tomato chlorosis virus, and simultaneous inoculation of both viruses in susceptible tomato cultivars leads to a rapid death of the plants (23).

Of all synergistic interactions between plant viruses described, the potyvirus-associated interactions, in combination with viruses belonging to other genera, are the best studied and generally produce a notable increase in host symptoms during a double infection when compared with a single infection. In most of these interactions, the accumulation of the potyvirus remains the same, whereas that of other viruses is increased $(5,26,51,53,68)$. Examples of such synergistic interactions are mixed infections with Potato virus $Y$ (PVY) (Potyvirus) and Potato virus $X$ (PVX) (Potexvirus) (51,70), Tobacco etch virus (Potyvirus) and Cucumber mosaic virus (CMV, Cucumovirus) or Tobacco mosaic virus (Tobamovirus) (51), and ZYMV and CMV (73). Subsequent research revealed that the potyviral RNA silencing suppressor protein P1/HC-Pro was involved in the synergistic effect, possibly by decreasing the targeting of the other virus by the RNA-silencing machinery $(10,68,69,71)$. The HC-Pro protein of plant potyviruses was initially identified as an accessory helper factor required during the plant-to-plant transmission process of potyviruses by aphid vectors (27), although it was shown later to have multiple roles in many essential processes of the potyvirus life cycle $(15,44,52,55)$.

Our results show that the ipomovirus CVYV significantly affected symptom expression and accumulation of CYSDV, whereas the potyvirus ZYMV did not. Interestingly, the genome from CVYV, as well as that from ipomoviruses Squash vein yellowing virus (SqVYV) and Cassava brown streak virus, lack HC-Pro coding sequences $(31,38,48)$. Perhaps this coding region has been lost during evolution, due to the lack of selective pressure on the HC-Pro, as a prerequisite for aphid transmission, because these three viruses are transmitted by WFs. However, recently, the CVYV genome was found to encode for P1a and P1b proteins, referred to collectively as a "duplicated" P1 protein

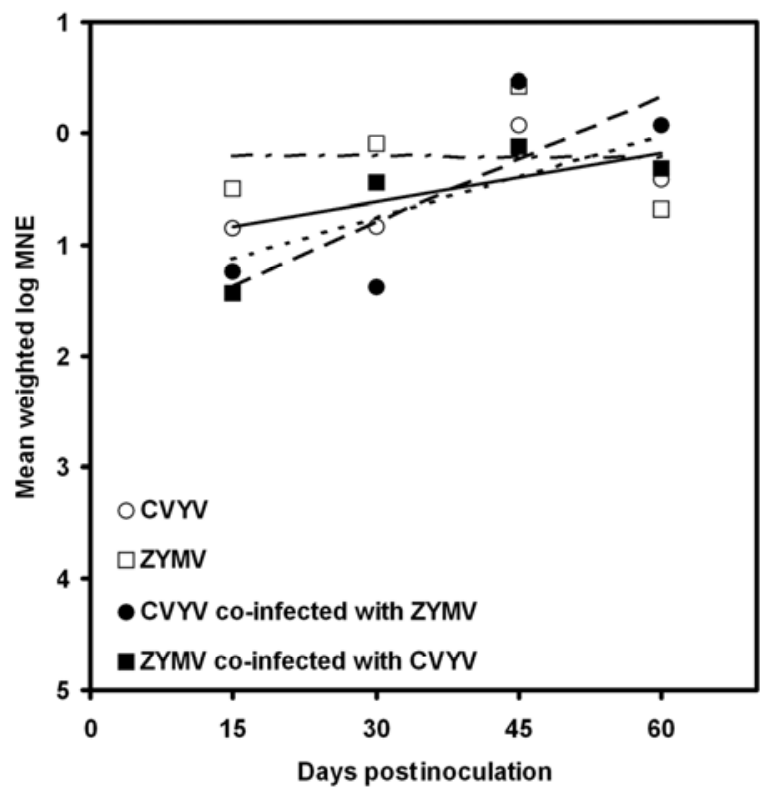

Fig. 4. Amounts (mean weighted log [mean normalized expression (MNE)]) against the number of days postinoculation in zucchini squash of Zucchini yellow mosaic virus (ZYMV) and Cucurbit vein yellowing virus (CVYV) during single and mixed infections. Average least significant difference between means was 0.6409 . 
$(66,67)$. CVYV P1b is believed to function as an HC-Pro homo$\log$ because it was demonstrated to function as a suppressor of gene silencing $(65,67)$. Although the genomes from the ipomoviruses CVYV and SqVYV encode sequences for proteins that can function as a suppressor of gene silencing under experimental conditions, nothing is known about possible synergistic effects when co-infected with other viruses under natural conditions. The results from the present article suggest that CVYV does have a synergistic effect on the co-infecting crinivirus CYSDV in terms of symptom expression and virus accumulation in zucchini squash. Further research should be carried out to see whether this effect is derived from the gene-silencing activity of CVYVexpressed P1b.

\section{ACKNOWLEDGMENTS}

F. M. Gil-Salas was supported by funding from IFAPA (C.A.P., Junta de Andalucía).

\section{LITERATURE CITED}

1. Abou-Jawdah, Y., Sobh, H., Fayad, A., Lecoq, H., Delécolle, B., and Trad-Ferré, J. 2000. Cucurbit yellow stunting disorder virus-a new threat to cucurbits in Lebanon. J. Plant Pathol. 82:55-60.

2. Accotto, G. P., Navas-Castillo, J., Noris, E., Moriones, E., and Louro, D. 2000. Typing of Tomato yellow leaf curl virus in Europe. Eur. J. Plant Pathol. 106:179-186.

3. Aguilar, J. M., Franco, M., Marco, C. F., Berdiales, B., Rodriguez-Cerezo, E., Truniger, V., and Aranda, M. A. 2003. Further variability within the genus Crinivirus, as revealed by determination of the complete RNA genome sequence of Cucurbit yellow stunting disorder virus. J. Gen. Virol. 84:2555-2564.

4. Al Musa, A. M., Qusus, S. J., and Mansour, A. N. 1985. Cucumber vein yellowing virus on cucumber in Jordan. Plant Dis. 69:361.

5. Anjos, J. R., Jarlfors, U., and Ghabrial, S. A. 1992. Soybean mosaic potyvirus enhances the titer of two comoviruses in dually infected soybean plants. Phytopathology 82:1022-1027.

6. Anonymous. 2007. Cucumber vein yellowing virus (Ipomovirus). Bull. OEPP/EPPO Bull. 37:554-559.

7. Bananej, K., Desbiez, C., Girard, M., Wipf-Scheibel, C., Vahdat, I., Kheyr-Pour, A., Ahoonmanesh, A., and Lecoq, H. 2006. First report of Cucumber vein yellowing virus on cucumber, melon, and watermelon in Iran. Plant Dis. 90:1113.

8. Bell, V. A., Bonfiglioli, R. G. E., Walker, J. T. S., Lo, P. L., Mackay, J. F., and McGregor, S. E. 2009. Grapevine leafroll-associated virus 3 persistence in Vitis vinifera remnant roots. J. Plant Pathol. 91:527-533.

9. Berdiales, B., Bernal, J., Sáez, E., Woudt, B., Beitia, F., and RodríguezCerezo, E. 1999. Occurrence of Cucurbit yellow stunting disorder virus (CYSDV) and Beet pseudo-yellows virus in cucurbit crops in Spain and transmission of CYSDV by two biotypes of Bemisia tabaci. Eur. J. Plant Pathol. 105:211-215.

10. Brigneti, G., Voinnet, O., Li, W. X., Ji, L. H., Ding, S. W., and Baulcombe, D. 1998. Viral pathogenicity determinants are suppressors of transgene silencing in Nicotiana benthamiana. EMBO J. 17:6739-6746.

11. Célix, A., López-Sesé, A., Almarza, N., Gómez-Guillamón, M. L., and Rodríguez-Cerezo, E. 1996. Characterization of Cucurbit yellow stunting disorder virus, a Bemisia tabaci-transmitted closterovirus. Phytopathology 86:1370-1376.

12. Céspedes, A. J., García, M. C., Pérez, J. J., and Cuadrado, I. M. 2009. Caracterización de la Explotación Hortícola Protegida de Almería. FIAPA, Almería, Spain.

13. Cohen, S., and Nitzany, F. E. 1960. A whitefly transmitted virus of cucurbits in Israel. Phytopathol. Mediterr. 1:44-46.

14. Consejería de Agricultura y Pesca 2009. Boletín semanal de información agraria no. 1001. Junta de Andalucía, Seville

15. Cronin, S., Verchot, J., Haldeman-Cahill, R., Schaad, M., and Carrington, J. 1995. Long-distance movement factor: a transport function of the potyvirus helper component proteinase. Plant Cell 7:549-559.

16. Cuadrado, I. M., Janssen, D., Velasco, L., Ruiz, L., and Segundo, E. 2001. First report of Cucumber vein yellowing virus in Spain. Plant Dis. 85:336.

17. Desbiez, C., Delecolle, B., Wipf-Scheibel, C., and Lecoq, H. 2001. Le Cucumber vein yellowing virus, virus transmis par l'aleurode Bemisia tabaci, est un member des Ipomovirus, Potyviridae. Page 31 in: 8èmes Rencontres de Virologie Végétale, Aussois, Strasbourg, France.

18. Desbiez, C., Lecoq. H., Aboulama. S., and Peterschmitt, P. 2000. First report of Cucurbit yellow stunting disorder virus in Morocco. Plant Dis. 84:596.
19. Desbiez, C., Lecoq, H., Girard, M., Cotillon, A. C., and Schoen, L. 2003. First report of Cucurbit yellow stunting disorder virus in commercial cucumber greenhouses in France. Plant Dis. 87:600.

20. Dietrich, D., and Maiss, E. 2003. Fluorescent labelling reveals spatial separation of potyvirus populations in mixed infected Nicotiana benthamiana plants. J. Gen. Virol. 84:2871-2876.

21. Dovas, C. I., Mamolos, A. P., and Katis, N. I. 2002. Fluctuations in concentration of two potyviruses in garlic during the growing period and sampling conditions for reliable detection by ELISA. Ann. Appl. Biol. 140:21-28.

22. Eid, S., Abou-Jawdah, Y., El-Mohtar, C., Sobh, H., and Havey, M. 2006. Tolerance in cucumber to Cucurbit yellow stunting disorder virus. Plant Dis. 90:645-649.

23. García-Cano, E., Resende, R. O., Fernández-Muñoz, R., and Moriones, E. 2006. Synergistic interaction between Tomato chlorosis virus and Tomato spotted wilt virus results in breakdown of resistance in tomato. Phytopathology 96:1263-1269.

24. Gil-Salas, F. M., Colyer, A., Boonham, N., Cuadrado, I. M., and Janssen, D. 2009. Resistance screening against Cucumber vein yellowing virus using a real-time (TaqMan) RT-PCR assay in cucumber (Cucumis sativus). Crop Prot. 28:109-112.

25. Gil-Salas, F. M., Morris, J., Colyer, A., Budge, G., Boonham, N., Cuadrado, I. M., and Janssen, D. 2007. Development of real-time RT-PCR assays for the detection of Cucumber vein yellowing virus (CVYV) and Cucurbit yellow stunting disorder virus (CYSDV) in the whitefly vector Bemisia tabaci. J. Virol. Methods 146:45-51.

26. Goldberg, K. B., and Brakke, M. K. 1987. Concentration of maize chlorotic mosaic virus increased in mixed infections with maize dwarf mosaic virus strain B. Phytopathology 77:162-167.

27. Govier, D. A., and Kassanis, B. 1974. A virus-induced component of plant sap needed when aphids acquire potato virus $Y$ from purified preparations. Virology 61:420-426.

28. Habili, N., Fazeli, C. F., and Rezaian, M. A. 1997. Identification of a cDNA clone specific to grapevine leafroll-associated virus 1 , and occurrence of the virus in Australia. Plant Pathol. 46:516-522.

29. Hassan, A. A., and Duffus, J. E., 1991. A review of a yellowing and stunting disorder of cucurbits in the United Arab Emirates. Emir. J. Agric. Sci. 2:1-16.

30. Janssen, D., and Cuadrado, I. M. 2001. Whitefly problems escalate within Spanish cucurbit crops. In: ESWN Newsletter no. 11. John Innes Centre, Norwich, UK.

31. Janssen, D., Martin, G., Velasco, L., Gomez, P., Segundo, E., Ruiz, L., and Cuadrado, I. M. 2005. Absence of a coding region for the helper component-proteinase in the genome of cucumber vein yellowing virus, a whiteflytransmitted member of the Potyviridae. Arch. Virol. 150:1439-1447.

32. Janssen, D., Ruiz, L., Velasco, L., Segundo, E., and Cuadrado, I. M. 2002. Non-cucurbitaceous weed species shown to be natural hosts of Cucumber vein yellowing virus in south-eastern Spain. Plant Pathol. 51:797.

33. Jones, D. R. 2003. Plant viruses transmitted by whiteflies. Eur. J. Plant Pathol. 109:195-219.

34. Kao, J., Jia, L., Tian, E., Rubio, L., and Falk, B. W. 2000. First report of Cucurbit yellow stunting disorder virus (genus Crinivirus) in North America. Plant Dis. 101:84.

35. Karyeija, R. F., Kreuze, J. F., Gibson, R. W., and Valkonen, J. P. 2000. Synergistic interactions of a potyvirus and a phloem-limited crinivirus in sweet potato plants. Virology 269:26-36.

36. Lecoq, H., Desbiez, C., Delécolle, B., Cohen, S., and Mansour, A. 2000. Cytological and molecular evidence that the whitefly transmitted Cucumber vein yellowing virus is a tentative member of the family Potyviridae. J. Gen. Virol. 81:2289-2293.

37. Lecoq, H., Dufour, O., Wipf-Scheibel, C., Girard, M., Cotillon, A. C., and Desbiez, C. 2007. First report of Cucumber vein yellowing virus in melon in France. Plant Dis. 91:909.

38. Li, W., Hilf, M. E., Webb, S. E., Baker, C. A., and Adkins, S. 2008. Presence of $\mathrm{P} 1 \mathrm{~b}$ and absence of HC-Pro in Squash vein yellowing virus suggests a general feature of the genus Ipomovirus in the family Potyviridae. Virus Res. 135:213-219.

39. Lin, C. S., Poushinsky, G., and Mauer, M. 1979. An examination of five sampling methods under random and clustered distribution using simulation. Can. J. Plant Sci. 59:121-130.

40. Liu, L. Z., Chen, Y. Y., and Zhu, W. M. 2010. First Report of Cucurbit yellow stunting disorder virus on melon in China. Plant Dis. 94:485-485.

41. Loebenstein, G., Fuentes, S., Cohen, J., and Salazar, L. F. 2003. Sweet potato. Pages 223-248 in: Virus and Virus-like Diseases of Major Crops in Developing Countries. G. Loebenstein and G. Thottappilly, eds. Kluwer Academic Publishers, Dordrecht, The Netherlands.

42. Louro, D., Quinot, A., Neto, E., Fernandes, J. E., Marian, D., Vecchiati, M., Caciagli, P., and Vaira, A. M. 2004. Occurrence of Cucumber vein yellowing virus in cucurbitaceous species in southern Portugal. Plant Pathol. 53:241. 
43. Louro, D., Vicente, M., Vaira, A. M., Accotto, G. P., and Nolasco, G. 2000. Cucurbit yellow stunting disorder virus (genus Crinivirus) associated with yellowing disease of cucurbit crops in Portugal. Plant Dis. 84:1156.

44. Maia, I. G., Haenni, A., and Bernardi, F. 1996. Potyviral HC-Pro: a multifunctional protein. J. Gen. Virol. 77:1335-1341.

45. Mansour, A., and Al-Musa, A. 1993. Cucumber vein yellowing virus: host range and virus vector relationships. J. Phytopathol. 137:73-78.

46. Marco, C. F., Aguilar, J. M., Abad, J., Gómez-Guillamón, M. L., and Aranda, M. A. 2003. Melon resistance to Cucurbit yellow stunting disorder virus is characterized by reduced virus accumulation. Phytopathology 93:844-852.

47. Matthews, R. E. F. 1991. Matthew's Plant Virology, 3rd ed. Academic Press, San Diego, CA.

48. Mbanzibwa, D. R., Tian, Y., Mukasa, S. B., and Valkonen, J. P. T. 2009. Cassava Brown Streak Virus (Potyviridae) encodes a putative Maf/HAM1 pyrophosphatase implicated in reduction of mutations and a P1 proteinase that suppresses RNA silencing but contains no HC-Pro. J. Virol. 83:69346940.

49. Moreno, P., Guerri, J., and Muñoz, N. 1990. Identification of Spanish strains of citrus tristeza virus by analysis of double-stranded RNA. Phytopathology 80:477-482.

50. Mukasa, S. B., Rubaihayo, P. R., and Valkonen, J. P. T. 2006. Interactions between a crinivirus, an ipomovirus and a potyvirus in coinfected sweetpotato plants. Plant Pathol. 55:458-467.

51. Pruss, G., Ge, X., Shi, X. M., Carrington, J. C., and Vance, V. B. 1997. Plant viral synergism: the potyviral genome encodes a broad-range pathogenicity enhancer that transactivates replication of heterologous viruses. Plant Cell 9:859-868.

52. Revers, F., Le Gall, O., Candresse, T., and Maule, A. J. 1999. New advances in understanding the molecular biology of plant/potyvirus interactions. Mol. Plant-Microbe Interact. 12:367-376.

53. Rochow, W. F., and Ross, A. F. 1955. Virus multiplication in plants doubly infected by potato viruses $\mathrm{X}$ and Y. Virology 1:10-27.

54. Rodriguez-Rodriguez, M. D., and Dana-Sanchez, E. 2008. Weed hosts of the whitefly Bemisia tabaci (Gennadius) on horticulture crops in southern Almería (Spain). Page 47 in: Abstr. 3rd Eur. Whitefly Symp. Aguadulce, Spain.

55. Rojas, M. R., Zerbini, F. M., Allison, R. F., Gilbertson, R. L., and Lucas, W. J. 1997. Capsid protein and helper component-proteinase function as potyvirus cell-to-cell movement proteins. Virology 237:283-295.

56. Rossel, H. W., and Thottappilly, G. 1988. Complex virus diseases of sweet potato. Pages 291-302 in: Exploration, Maintenance and Utilization of Sweet Potato Genetic Resources. Rep. 1st Sweet Potato Planning Conf. International Potato Center, Lima, Peru.

57. Rubio, L., Abou-Jawdah, Y., Lin, H. X., and Falk, B. W. 2001. Geographically distant isolates of the crinivirus Cucurbit yellow stunting disorder virus show very low genetic diversity in the coat protein gene. J. Gen. Virol. 82:929-933.

58. Rubio, L., Janssen, D., Cuadrado, I. M., Moreno, P., and Guerra, J. 2003. Rapid detection of Cucumber vein yellowing virus by tissue-print hybridisation with digoxigenin-labelled cDNA probes. J. Virol. Methods 114:105-107.

59. Rubio, L., Soong, J., Kao, J., and Falk, B. W. 1999. Geographic distribution and molecular variation of isolates of three whitefly-borne closteroviruses of cucurbits: Lettuce infectious yellows virus, Cucurbit yellow stunting disorder virus, and Beet pseudo-yellows virus. Phytopathology 89:707-711

60. Ruiz, L., Janssen, D., Martin, G., Velasco, L., Segundo, E., and Cuadrado, I. M. 2006. Analysis of the temporal and spatial disease progress of
Bemisia tabaci-transmitted Cucurbit yellow stunting disorder virus and Cucumber vein yellowing virus in cucumber. Plant Pathol. 55:264-275.

61. Savenkov, E. I., and Valkonen, J. P. T. 2001. Potyviral helper-component proteinase expressed in transgenic plants enhances titers of Potato leaf roll virus but does not alleviate its phloem limitation. Virology 283:285293.

62. Schaefers, G. A., and Terry, E. R. 1976. Insect transmission of sweet potato disease agents in Nigeria. Phytopathology 66:642-645.

63. Sese, A. L., Gomez-Guillamon, M. L., and Diaz-Ruiz, J. R. 1994. Appearance of a possibly new yellowing disease in Spain. Cucurbit Gen. Coop. 17:72-73.

64. Susaimuthu, J., Tzanetakis, I. E., Gergerich, R. C., Kim, K. S., and Martin, R. R. 2008. Viral interactions lead to decline of blackberry plants. Plant Dis. 92:1288-1292.

65. Valli, A., Dujovny, G., and Garcia, J. A. 2008. Protease activity, self interaction and siRNA binding of the silencing suppressor P1b from Cucumber vein yellowing ipomovirus. J. Virol. 82:974-986.

66. Valli, A., Lopez-Moya, J. J., and Garcia, J. A. 2007. Recombination and gene duplication in the evolutionary diversification of $\mathrm{P} 1$ proteins in the family Potyviridae. J. Gen. Virol. 88:1016-1028.

67. Valli, A., Martın-Hernandez, A. M., Lopez-Moya, J. J., and Garcia, J. A. 2006. RNA silencing suppression by a second copy of the P1 serine protease of Cucumber vein yellowing ipomovirus, a member of the family Potyviridae that lacks the cysteine protease HCPro. J. Virol. 80:1005510063

68. Vance, V. B. 1991. Replication of Potato virus X RNA is altered in coinfections with Potato virus $Y$. Virology 182:486-494.

69. Vance, V. B. 1999. Synergism: plant viruses. Pages 1694-1699 in: Encyclopedia of Virology, 2nd ed. A. Granoff and R. G. Webster, eds. Academic Press, San Diego, CA.

70. Vance, V. B., Berger, P. H., Carrington, J. C., Hunt, A. G., and Shi, X. M. 1995. 5' proximal potyviral sequences mediate potato virus $X /$ potyviral synergistic disease in transgenic tobacco. Virology 206:583-590.

71. Voinnet, O., Pinto, Y. M., and Baulcombe, D. C. 1999. Suppression of gene silencing: a general strategy used by diverse DNA and RNA viruses of plants. Proc. Nat. Acad. Sci. USA 96:14147-14152.

72. Wang, J., Turina, M., Medina, V., and Falk, B. W. 2009. Synergistic interaction between the Potyvirus, Turnip mosaic virus and the Crinivirus, Lettuce infectious yellows virus in plants and protoplasts. Virus Res. 144:163-170.

73. Wang, Y., Gaba, V., Yang, J., Palukaitis, P., and Gal-On, A. 2002. Characterization of synergy between Cucumber mosaic virus and potyviruses in cucurbit hosts. Phytopathology 92:51-58.

74. Wintermantel, W. M. 2005. Co-infection of Beet mosaic virus with beet yellowing viruses leads to increased symptom expression on sugar beet. Plant Dis. 89:325-331.

75. Wintermantel, W. M., Brown, J. K., and Gilbertson, R. L. 2007. Widespread emergence of Cucurbit yellow stunting disorder virus (CYSDV) in the southwestern desert melon production region of the United States and Mexico. (Abstr.) Phytopathology 97:S124.

76. Wisler, G. C., and Duffus, J. E. 2001. Transmission properties of whitefly-borne criniviruses and their impact on virus epidemiology. Pages 293-308 in: Virus-Insect-Plant Interactions. K. F. Harris, O. P. Smith, and J. E. Duffus, eds. Academic Press, San Diego, CA.

77. Yakoubi, S., Desbiez, C., Fakhfakh, H., Wipf-Scheibel, C., Marrakchi, M., and Lecoq, H. 2007. Occurrence of Cucurbit yellow stunting disorder virus and Cucumber vein yellowing virus in Tunisia. J. Plant Pathol. 89:417-420.

78. Yimaz, M. A., Ozaslan, M., and Ozaslan, D. 1989. Cucumber vein yellowing virus in Cucurbitaceae in Turkey. Plant Dis. 73:610. 